\title{
Seroepidemiology of HTLV-III antibody in Danish homosexual men: prevalence, transmission, and disease outcome
}

\author{
MADS MELBYE, ROBERT J BIGGAR, PETER EBBESEN, M G SARNGADHARAN, \\ STANLEY H WEISS, ROBERT C GALLO, WILLIAM A BLATTNER
}

\begin{abstract}
Sera taken from 250 Danish homosexual men in December 1981 as part of a prospective study of the acquired immunodeficiency syndrome (AIDS) were examined for the presence of HTLV-III antibody with an enzymelinked immunosorbent assay. Antibody was present in 22 $(8.8 \%)$ of the men. Seropositivity was most strongly associated with sexual exposure to men in the United States (relative risk $3.5 ; p<0.007$ ). Increased frequency of anal receptive intercourse was also independently associated with seropositivity $(p<0.05)$, but age, years of homosexual experience, number of homosexual partners, and use of nitrite inhalant were not independent risk factors. The frequency of seroconversion from absence to presence of HTLV-III antibody appeared to be about $1 \%$ a month in this community during December 1981 to February 1983. Of the 22 men who were originally seropositive, two ( $9 \%$ ) subsequently developed AIDS as defined by the Centre for Disease Control and two ( $9 \%$ ) others the AIDS related complex. Blood was taken in addition from two of the men to develop AIDS earliest in Denmark (diagnosed 1981) at the same time as the initial survey in 1981; both were seropositive.
\end{abstract}

Institute of Cancer Research, Radiumstationen, 8000 Aarhus, Denmark

MADS MELBYE, MD, medical staff fellow

PETER EBBESEN, MD, chief

Environmental Epidemiology Branch, National Cancer Institute, Bethesda, Maryland 20205, USA

ROBERT J BIGGAR, MD, medical epidemiologist

STANLEY $H$ WEISS, MD, medical staff fellow

WILLIAM A BLATTNER, MD, chief of family studies section

Department of Cell Biology, Litton Bionetics Inc, Maryland 20895, USA

M G SARNGADHARAN, MD, chief of seroepidemiology section

\footnotetext{
Laboratory of Tumor Cell Biology, National Cancer Institute, Bethesda

ROBERT C GALLO, MD, chief

Correspondence to: Dr M Melbye.
}

The spread of HTLV-III from high to low risk areas and the subsequent appearance of illnesses related to AIDS in the seropositive group support the hypothesis that HTLV-II is causally related to the development of AIDS.

\section{Introduction}

Recent reports have suggested that the newly described human T lymphotropic retrovirus HTLV-III is the probable cause of the acquired immunodeficiency syndrome (AIDS). ${ }^{12}$ The initial studies reported that the agent could be isolated from patients with AIDS and that more than $80 \%$ of patients with AIDS had antibody to this agent. ${ }^{3}$ Homosexual men are known to be at increased risk of developing AIDS, ${ }^{4}$ and both isolation of the virus ${ }^{2}$ and a high prevalence of antibody to HTLV-III ${ }^{3}$ have been seen in this group. Studies among patients with AIDS and members of groups at risk in Europe have shown similar results for the lymphadenopathy virus isolated in France. ${ }^{5-7}$ HTLV-III may be closely related or identical.

With the availability of serological tests to detect antibody to HTLV-III, ${ }^{8}$ the distribution and determinants of seropositivity can now be determined. This report describes the extent of exposure, provides clues to the means of transmission of the agent, and shows the relation between seroconversion and subsequent illness. We studied Danish homosexual men to examine the introduction of HTLV-III into an area initially at low risk for developing AIDS.

\section{Subjects and methods}

In December 1981170 men in Copenhagen and 89 in Aarhus (259) were enrolled through invitations mailed by a nationwide organisation for homosexuals in Denmark. Those enrolled donated sera and completed a self administered questionnaire about lifestyle. The design of the study and characteristics of this group have been presented in previous reports concerning sexual practices and exposure to drugs, patterns of antibodies against Epstein-Barr virus and cytomegalovirus, ${ }^{9}$ and excretion of cytomegalovirus. ${ }^{10}$ Sera were still available for 250 men. A subset of 40 of these men which was subsequently reinterviewed and examined in April 1982 and February 1983 was also serologically analysed. ${ }^{11} 12$ The present study focused on the presence of antibody to HTLV-III in the study population, relating it to lifestyle and 
clinical outcome. In addition, we interviewed two of the three original patients to develop AIDS in Denmark (the third had died), all from Copenhagen, ${ }^{13}$ who donated sera and have been reported on below.

Antibody to HTLV-III was measured by an enzyme-linked immunosorbent assay in which disrupted whole virus was the substrate. ${ }^{8}$ Samples were run in duplicate and a known negative control run eight times on each plate, with the results for each averaged. Sample results were compared with negative control results by calculating the ratio of the two values. Initial reports from this laboratory used a ratio of $\geqslant 3.0$ as the positive threshold, but a few men without AIDS who had ratios between 3.0 and 5.0 were not confirmed as having antibody to HTLV-III when tested by the Western blot technique (unpublished data). We therefore used a ratio of sample to background of $\geqslant 5.0$ as the criterion for seropositivity and considered a ratio between 3.0 and 5.0 to be borderline.

Statistical comparisons were made between seropositive and seronegative subjects, with those in the borderline zone excluded. Associations were analysed by $\chi^{2}$ test, Spearman rank order correlations, odds ratios, trend analyses, and linear regression. ${ }^{14-16}$

\section{Results}

\section{CASE REPORTS}

Case 1 was a 50 year old man who had been a practising homosexual for 40 years. He had had extensive contact with homosexuals in the United States (at least 30 partners a year in bathhouse or backroom settings) during annual visits to New York City between 1971 and 1981. During the winter of 1980-1 he noted lymphadenopathy, and Kaposi's sarcoma was diagnosed in early 1981 on the basis of a biopsy of a small skin nodule. During follow up he received no treatment but the disease progressed little. His serum was positive for HTLV-III antibody when first tested in December 1981 (ratio=13.7) and continued to be seropositive on two subsequent visits (ratios $=16.1$ and $11 \cdot 0)$.

Case 2 was a 37 year old homosexual man who denied having visited the United States in 1980-1. He was, however, a frequent sexual partner of the first man to develop AIDS in Denmark (who died of Pneumocystis carinii pneumonia and Kaposi's sarcoma in the summer of 1981). In the autumn of 1981 he developed recurrent fevers, lymphadenopathy, and extreme loss of weight. When we obtained serum from him he was terminally ill. The HTLV-III antibody ratio was positive $($ ratio $=5 \cdot 1)$.

\section{HEALTHY HOMOSEXUAL MEN}

The mean age of the participants in our study was 32.9 years They reported an average of 12.1 years of homosexual experience and an average of 22.2 (median 10 ) partners a year. HTLV-III antibodies were present in sera of $22(8.8 \%)$ of 250 Danish homosexual men (Copenhagen $16(9 \cdot 8 \%)$; Aarhus $6(7 \cdot 1 \%)$ ) from whom blood had been taken in December 1981. In contrast, none of 69 Danish blood donors matched for age and sex from whom blood was taken in the same period was seropositive.

TABLE I-Correlation between presence or absence of antibody to HTLV-III and known exposure to populations at risk of developing AIDS during 1980 and 1981. Values are numbers $(\%)$ of men

\begin{tabular}{|c|c|c|c|c|}
\hline & \multicolumn{3}{|c|}{ Assay for HTLV-III antibody } & \multirow{2}{*}{$\begin{array}{c}\text { Relative risk } \\
(95 \% \text { confidence } \\
\text { limits })^{\dagger}\end{array}$} \\
\hline & Negative & Borderline & Positive & \\
\hline \multicolumn{5}{|c|}{ Visit to USA during $1980-1$ : } \\
\hline $\begin{array}{l}\text { Yes }(n=43) \\
\text { No }(n=202)\end{array}$ & $\begin{array}{r}32(74) \\
182(90)\end{array}$ & $\begin{array}{ll}3 & (7) \\
7 & (3)\end{array}$ & $\left.\begin{array}{r}8(19) \\
13(6)\end{array}\right]$ & \multirow{2}{*}{$\begin{array}{l}3 \cdot 5(1 \cdot 2-9 \cdot 9) \\
1 \cdot 0\end{array}$} \\
\hline $\begin{array}{l}\text { No data } \neq(n=5) \\
\text { Total }(n=250)\end{array}$ & $\begin{array}{r}4(80) \\
218(87)\end{array}$ & 10 & $\begin{array}{r}12(20) \\
22\end{array}$ & \\
\hline \multicolumn{5}{|c|}{$\begin{array}{l}\text { Total }(n=250) \text { ( } 218(87) \\
\text { Partners from USA but no visit to USA: }\end{array}$} \\
\hline $\begin{array}{l}\text { Yes }(n=63) \\
\text { No }(n=129) \\
\text { No data } \$(n=10) \\
\text { Total }(n=202)\end{array}$ & $\begin{array}{r}57(91) \\
119(92) \\
6(60) \\
182(90)\end{array}$ & $\begin{array}{l}1(2) \\
4(3) \\
2(20) \\
7(3)\end{array}$ & $\left.\begin{array}{r}5(8) \\
6(5) \\
2(20) \\
13(6)\end{array}\right\}$ & $\frac{1 \cdot 7(0 \cdot 4-7 \cdot 1)}{1 \cdot 0}$ \\
\hline \multicolumn{5}{|c|}{$\begin{array}{l}\text { Total }(n=202) \\
\text { Partners with pneumonia or cancer among non-visitors to USA and those denying } \\
\text { sexual contact with men from USA: }\end{array}$} \\
\hline $\begin{array}{l}\text { sexual contact wit } \\
\text { Yes }(n=1)\end{array}$ & & & & \\
\hline $\begin{array}{l}\text { No }(n=125) \\
\text { No data } f(n=3)\end{array}$ & $116(9$ & $4(3)$ & & $1 \cdot 0^{(0 \cdot 7-}$ \\
\hline \multirow{2}{*}{\multicolumn{5}{|c|}{$\begin{array}{l}\text { Total }(n=129) \\
\text { Total known exposure to any population at risk of developing AIDS: } \\
\text { Yes }(n=107)\end{array}$}} \\
\hline & & & & \\
\hline No $(n=125)$ & $116(93)$ & & $5(4)\}$ & 1.0 \\
\hline
\end{tabular}

* Calculation of relative risk compared seropositive with seronegative subjects.

$\$$ Exact confidence limits.
TABLE II-Correlation between presence or absence of antibody to HTLV-III and exposure to different variables of sexual behaviour in the previous year. $V$ alues are numbers ( $\%$ ) of men

\begin{tabular}{|c|c|c|c|c|c|}
\hline & \multicolumn{4}{|c|}{ Assay for HTLV-III antibody } & \multirow{2}{*}{$\begin{array}{c}\text { Relative risk } \\
(95 \% \text { confidence } \\
\text { limits)* }\end{array}$} \\
\hline & Negative & Borderline & Positive & Total & \\
\hline \multicolumn{2}{|c|}{$\begin{array}{cc}\text { No of sexual partners } \\
\leqslant 9 & 78(92) \\
10-19 & 41(91) \\
20-49 & 45(83) \\
\geqslant 50 & 27(84) \\
\text { No data } & 27(79)\end{array}$} & $\begin{array}{l}4(5) \\
2(4) \\
3(6) \\
1(3)\end{array}$ & $\begin{array}{l}3(4) \\
2(4) \\
6(11) \\
5(16) \\
6(18)\end{array}$ & $\begin{array}{l}85 \\
45 \\
54 \\
32 \\
34\end{array}$ & $\begin{array}{r}1.0 \\
1.3(0.1-11.5) \\
3.5(0.7-22.2) \\
4.8(0.9-32.5)\end{array}$ \\
\hline $\begin{array}{l}\text { Receptive an } \\
\text { None } \\
\text { Seldom } \\
\text { Moderate } \\
\text { Frequent } \\
\text { No data }\end{array}$ & $\begin{array}{l}\text { intercourse: } \ddagger \\
54(87) \\
75(91) \\
59(86) \\
13(68) \\
17(94)\end{array}$ & $\begin{array}{l}4(6) \\
2(2) \\
3(4) \\
1(5)\end{array}$ & $\begin{array}{l}4(6) \\
5(6) \\
7(10) \\
5(26) \\
1(6)\end{array}$ & $\begin{array}{l}62 \\
82 \\
69 \\
19 \\
18\end{array}$ & $\begin{array}{l}1.0 \\
0.9(0.9-4.8) \\
1.6(0.4-7.9) \\
5.2(0.9-29.3) \\
\times \text { for trend }=2.02+\end{array}$ \\
\hline $\begin{array}{l}\text { Receptive or } \\
\text { None } \\
\text { Seldom } \\
\text { Moderate } \\
\text { Frequent } \\
\text { No data }\end{array}$ & $\begin{array}{l}\text { intercourse: } \ddagger \\
38(79) \\
95(89) \\
58(88) \\
10(91) \\
17(94)\end{array}$ & $\begin{array}{l}5(10) \\
4(4) \\
1(2)\end{array}$ & $\begin{array}{l}5(10) \\
8(7) \\
7(11) \\
1(9) \\
1(6)\end{array}$ & $\begin{array}{r}48 \\
107 \\
76 \\
11 \\
18\end{array}$ & $\begin{array}{l}1.0 \\
0.6(0.2-2 \cdot 7) \\
0.9(0 \cdot 2-4.0) \\
0.8(0.2-8 \cdot 1) \\
\end{array}$ \\
\hline $\begin{array}{l}\text { Use of nitrite } \\
\text { None } \\
1-19 \\
\geqslant 20 \\
\text { No data }\end{array}$ & $\begin{array}{c}\text { nhalant (days } \\
157(91) \\
38(79) \\
16(84) \\
7(70)\end{array}$ & $\begin{array}{l}\text { of exposure): } \\
7(4) \\
2(4) \\
1(10)\end{array}$ & $\begin{array}{l}9(5) \\
8(17) \\
3(16) \\
2(20)\end{array}$ & $\begin{array}{r}173 \\
48 \\
19 \\
10\end{array}$ & $\begin{array}{l}x . \text { for trend }=0.05 \\
1.0 \\
3.7(1 \cdot 1-11.4) \\
3.3(0.5-14.8) \\
\chi \text { for trend }=2.50 \dagger\end{array}$ \\
\hline
\end{tabular}

\$ Scale: seldom: up to once a mionth; moderate: more than once a month up to twice a week; frequent: more than twice a week.

Exact confidence limits.

$+\mathrm{p}<0.05$.

Seropositivity to HTLV-III was significantly associated with travel to the United States in 1980-1 $(\mathrm{p}<0.007)$ (table I). Travel histories were known for 21 men positive for HTLV-III antibodies. Of them, eight $(38 \%)$ had visited the United States compared with $32(15 \%)$ of 214 seronegative subjects. All seropositive Danish homosexual men visiting the United States had been to New York, San Francisco, or Los Angeles whereas only $16(50 \%)$ of the seronegative visitors had been to these cities. Furthermore, seropositivity correlated significantly with number of sexual partners in the United States $(p<0.02$, $\chi^{2}$ test). Of the 43 men who had visited the United States, eight $(18.6 \%)$ were positive for antibodies to HTLV-III compared with $13(6.4 \%)$ of the 202 non-visitors ( $p<0.007, \chi^{2}$ test). Of the 13 men with antibody to HTLV-III who denied having visited the United States, five had had sexual contact with American citizens outside the United States, and one had had frequent sexual contacts with a man (the first in Denmark to develop AIDS) who died of Kaposi's sarcoma and pneumocystis pneumonia. In summary, $14(74 \%)$ of the 19 seropositive subjects had been sexually exposed in 1980 to men in the United States to American citizens in Europe, or to a European man with AIDS. Data were incomplete on three seropositive subjects.

The number and type of sexual acts also appeared to be significantly associated with likelihood of seropositivity for HTLV-III antibody (table II). An increase in the number of sexual partners was associated with HTLV-III seropositivity $(p<0.03)$. The number of acts as the recipient of anal intercourse correlated with seropositivity $(p<0.03)$ whereas being a recipient of oral intercourse or the donor in either form of intercourse did not appear to be important. Seropositivity for HTLV-III antibody was also associated in univariate correlations with use of nitrite inhalant $(p<0.008)$. In contrast, there was no association between seropositivity and age or duration of homosexual experience.

The sexual behaviour of the men visiting the United States did not differ appreciably from that of those not visiting the United States. All variables, however, found to be significant in the univariate analyses were forced into a linear regression model to permit adjustment for interrelations. The association between visiting the United States and seropositivity for HTLV-III antibody remained strong $(p<0.02)$ after adjusting for number of partners, anal receptive intercourse, and use of nitrate. Receptive anal intercourse was the only other independently correlated variable $(p<0.05)$.

\section{PROSPECTIVE FOLLOW UP}

In the follow up studies two of 34 initially seronegative men were shown to have become seropositive by five months later (April 1982), and an additional two of the remaining 31 men had become seropositive by February 1983 . Thus the rate of seroconversion between 
December 1981 and April 1982 was $1.2 \%$ a month and between April 1982 and February 1983, 0.7\% a month. In addition, seroconversion occurred in one of five men who were tested only in December 1981 and February 1983 (1.3\% a month). The small numbers affected limit statistical analysis, but it is noteworthy that two of the five in whom seroconversion occurred had visited the United States (one in 1981 only and the other several times, including in 1982) and that the remaining three had all had sexual contact with American citizens during the same period. Clinically, of the 22 originally seropositive men two $(9 \%)$ were subsequently found to have AIDS according to the definition of the Centre for Disease Control and two others $(9 \%)$ developed the AIDS related complex.

\section{Discussion}

These findings indicate dissemination of HTLV-III from an area of high risk for AIDS to an area of low risk with the concomitant appearance of AIDS in the area of low risk, which is the pattern to be expected if this retrovirus is, in fact, linked aetiologically to the disease. Before the discovery of HTLV-III, attempts to understand the epidemic initially focused on AIDS illness. In a case control study in New York City, a high risk area, anal receptive intercourse and number of sexual partners were found to be important variables in lifestyle affecting the risk of developing AIDS. ${ }^{1718}$ In Denmark, however, because of the relatively few cases of AIDS, we used abnormalities of lymphocyte subsets as a surrogate marker for risk of developing AIDS. ${ }^{11}$ In this community, far from the epicentres of AIDS in the United States we found that homosexual exposure to men in the United States was the most important lifestyle factor. ${ }^{11}$ Both exposure to men from high risk areas and anal receptive intercourse were subsequently confirmed to be associated with lymphocyte subset abnormalities in another study of homosexual men in New York and Washington DC (Goedert et al. Decreased helper $\mathrm{T}$ lymphocytes in homosexual men. I and II. To be published). With the availability of the serological assay for antibody to HTLV-III, surrogate markers such as T cell subset abnormalities may prove less informative as a measure of susceptibility to AIDS. Such markers, however, could still be useful in understanding the complex interrelation between host factors and environment that results in the development of clinical AIDS.

The data from the present study are consistent with the hypothesis that HTLV-III entered the homosexual community in Denmark through sexual contact between Danish men and men from high risk areas. In a parallel study done in New York City in April 1982 (35 (53\%) of the 66 homosexual men examined were seropositive (James J Goedert, personal communication), suggesting extensive dissemination of this virus. The results indicate that seropositivity first appeared in Denmark among Danish homosexual men who had visited the United States. After the introduction of the agent into the Danish homosexual community, person to person spread probably occurred. One of the three Danish men to develop AIDS even before our survey (described above) may have acquired HTLVIII through sexual contact with the first man in Denmark to develop AIDS, with whom he had frequent sexual relations even after the onset of AIDS related illness. Among the healthy men initially enrolled we could account for a possible route of exposure (visit to the United States, exposure to an American man in Europe, or exposure to a subject with a possible case of AIDS) in $14(74 \%)$ of 19 men who answered the relevant questions (table I). All five of those in whom seroconversion occurred during the study had had sexual contact with an American homosexual man, either in the United States or in Europe.

In addition to exposure to American homosexual men, sexual behaviour undoubtedly influenced the probability of being infected. We found univariate correlations between number of sexual partners, frequency of anal receptive intercourse, and use of nitrite inhalant. Oral receptive intercourse appeared to be slightly protective, probably because the men who denied performing this act were more likely to be practising anal receptive intercourse. After adjusting for visits to the United States, only increasing frequency of anal receptive intercourse remained significantly associated with likelihood of being seropositive.

At the beginning of this study (December 1981) Denmark had only three cases of AIDS, all diagnosed during 1981. Even at this relatively early point in the epidemic, however, $22(9 \%)$ of the homosexual subjects in our study were seropositive for antibody to HTLV-III, an indication of earlier exposure. Subsequent follow up of seronegative men indicated that the rate of seroconversion in this community over the subsequent 15 months was about $1 \%$ a month. There was no evidence that the rate of seroconversion was increasing. We suspect that this lack of increase may be because members of the study adopted a more conservative lifestyle after the publicity about AIDS.

The relation between presence of antibody and illness related to AIDS (Centre for Disease Control definition AIDS or AIDS related complex) is of paramount concern to those at risk. In this study, all men developing illnesses related to AIDS were seropositive before AIDS was diagnosed. Thus in the 22 initially seropositive men the minimal rate of developing AIDS as defined by the Centre for Disease Control (two cases) or the AIDS related complex (two cases) in the 28 months of follow up was $8 \%$ a year. Because our follow up was incomplete owing to the anonymous conditions in which the men were enrolled initially, it could well be higher.

These data provide strong evidence that HTLV-III is causally linked with the development of AIDS and that the risk of becoming infected is related both to exposure to homosexual men from high risk areas and to anal receptive intercourse. So far, only a small proportion of seropositive men have become ill with conditions related to AIDS despite more than two years' follow up. With changes in sexual habits and the availability of a test for screening, it is hoped that the further spread of the infection will be limited.

This study was supported by the Danish Cancer Society (contract No 84-003) and the National Cancer Institute, Bethesda (contract No 1-CP-21007).

\section{References}

1 Popovic M, Sarngadharan MG, Read E, Gallo RC. Detection, isolation, and continuous production of cytopathic retrovirus (HTLV-III) from patients with

2 Gallo RC Salahuddin SZ, Popovic M et al. Frequent detection and isolation of cytopathic retroviruses (HTLV-III) from patients with AIDS and at risk for AIDS. Science $1984 ; 224: 500-3$.

3 Schupbach J, Popovic M, Gilden RV, Gonda MA, Sarngadharan MG, Gallo RC. Serological analysis of a subgroup of human T-lymphotropic retroviruses
(HTLV-III) associated with AIDS. Science 1984;224:503-5. 4 Allen JR. AIDS in the United States. In: Ebbesen P, Biggar Rj, Melbye M, eds.

5 Brun-Vezinet F, Rouzioux C, Barre-Sinoussi F, et al. Detection of IgG antibodies to lymphadenopathy associated virus (LAV), in patients with acquired immunodeficiency syndrome or lymphadenopathy syndrome. Lancet 1984 ; : 1253-6.

6 Barre-Sinoussi F, Chermann JC, Rey F, et al. Isolation of a T-lympho tropic retrovirus from a patient at risk for acquired immune deficiency syndrome (AIDS). Science 1983;220:868-70

7 Melbye M, Biggar RJ, Chermann JC, Montagnier L, Stenbjerg S, Ebbesen P. High prevalence of lymphadenopathy virus (LAV) in Europeon haemophiliacs.

8 Sarngadharan MG, Popovic M, Bruch L, Schupbach J, Gallo RC. Antibodies reactive with o human T-lymphotropic retrovirus (HTLV-III) in the serum of reactive with a human T-lymphotropic retrovirus (HTL-11) in the serum of
patients with AIDS. Science 1984;224:506-8.

9 Melbye M, Biggar RJ, Ebbesen P, Andersen HK, Vestergaard BF, Lifestyle and antiviral antibody studies among homosexual men in Denmark. Acta Pathol Microbiol Immunol Scand [B] 1983;91:357-64.

10 Biggar RJ, Andersen HK, Ebbesen P, et al. Seminal fluid excretion of cytomegalovirus related to immunosuppression in homosexual men. Br Med $71983 ; 286$. 2010-2.

11 Biggar Rj, Melbye M, Ebbesen P, et al. Low T-lymphocyte ratios in homosexua men. Epidemiologic evidence for a transmissible agent. $\mathcal{F} A M A 1984 ; 251$. $1441-6$.

12 Schonheyder H, Melbye M, Biggar RJ, Ebbesen P, Neuland CY, Stenderup A Oral yeast flora and antibodies to Candida Albicans in homosexual men. Mykosen (in press)

13 Gerstoft J, Malchow-Moller A, Bygberg I, et al. Severe acquired immunodeficiency in European homosexual men. Br Med $\mathcal{f} 1982 ; 285: 17-9$.

14 Lehmann EL. Non parametrics: statistical methods based on rank. San Francisco: Holden-Day, 1975.

15 Thomas DG. Exact and asymptotic methods for the combination of $2 \times 2$ tables. Comput Biomed Res 1975;8:223-6.

16 Draper NR, Smith H. Applied regression analysis. New York: John Wiley, 1966

17 Marmor M, Friedman-Kien AE, Laubenstein L, et al. Risk factors for Kaposi's sarcoma in homoserual men. Lancet $1982 ; \mathrm{i}: 1083-7$.

$18 \mathrm{Jaffe} \mathrm{HW}$, Choi K, Thomas PA, et al. National case-control study of Kaposi's sarcoma and Pneumocystic carinii pneumonia in homosexual men. Part I. Epidemiologic results. Ann Intern Med 1983;99:145-51.

(Accepted 9 August 1984) 